\title{
THE NON-CYPRIANIC SCRIPTURE TEXTS \\ IN LACTANTIUS' DIVINE INSTITUTES
}

\author{
BY
}

\section{PAUL MCGUCKIN}

The state of the textual tradition regarding the Lactantian citations of scripture is in need of radical revision. When S. Brandt prepared his critical text in the CSEL' series in 1897, Hartel's previous edition of Cyprian's Ad Quirinum, in the same series, was used as his major authority in establishing which Lactantian manuscripts to follow in deciding the scriptural text Lactantius presented. The result was to emphasise congruity between the Cyprianic and Lactantian versions of scriptual pericopes. Brandt's editiorial premiss was that Lactantius' scriptural knowledge came directly and substantially from Cyprian, and consequently he edited the text of the $D I$ usually in accordance with the Cyprianic text established by Hartel. The critical edition of Cyprian's Ad Quirinum prepared most recently by $\mathrm{R}$. Weber, ${ }^{2}$ however, has radically revised the text of Hartel and reversed the latter's overriding belief in the accuracy of the single most ancient manuscript of Cyprian. Consequently Brandt's establishment of the Lactantian versions of scripture in the $D I^{3}$ stands in need of its own revision. Yet even though Brandt's edition of the $D I$ tends to overemphasise the congruities between Lactantius' biblical text and that of Cyprian it is still patently clear that the Lactantian versions, more often than not, represent significant differences in detail. So even where there is a clear parallel of the scriptural usage of the Ad Quirinum, the extent of the divergences give rise to questions over Lactantius' real source for the citation. It is perhaps impossible ever to establish which biblical version Lactantius was using, and most of the difficulties lie in the area of deciding whether the variants of citation represent an entirely different source, or whether they can be attributed to the free manner in which Lactantius treats all his textual authorities. The problem is further complicated in the fact that there appears to have been no consistent archetype of Cyprian's Ad Quirinum, and no uniform text of the pre-Vulgate Latin Bible; ${ }^{4}$ and 
the Lactantian manuscripts themselves propose successive modifications of what Lactantius wrote.

It is clear enough that Lactantius certainly did use the Ad Quirinum as a scripture manual, but perhaps not in so dependent a manner as previous commentators have presumed. Cyprian presents his selected quotations under theological headings which Lactantius, in his book of christology, uses as a guide in his presentation of the life of Jesus. ${ }^{5}$

R. M. Ogilvie comments on the great majority of scriptual citations in Lactantius that have a ready parallel in Cyprian's $A d$ Quirinum, ${ }^{6}$ and continues: "there are detailed textual similarities in a number of the quotations which point to some mutual interdepence." 'While Ogilvie's analysis is the only study of the problem available in English, and has the added advantage of being aware of Wlosok's study, ${ }^{8}$ it unfortunately relies wholly on the scriptural index of Brandt's text in the CSEL series. This is not only incomplete as it stands, but it omits the important evidence of scriptural allusions in the $D I$ and thus falsifies the whole picture of Lactantius' scriptural knowledge. The result is that an otherwise excellent work is marred by its sources. Ogilvie concludes, for example, that there are a total of 73 scripture passages in Book 4 of the $D I, 19$ of which have no parallel in Cyprian. ${ }^{9}$ Of these 73 passages three are Gospel references, ${ }^{10}$ and if we except these we thus have, on Ogilvie's reckoning, 70 OT passages, 17 of which have no Cyprianic authority. The present author has completely revised Brandt's scriptural index, however, to re-assess the biblical awareness of Lactantius and to include not only his direct citations but also the many textual allusions he makes to biblical logia. ${ }^{\prime \prime}$ The revised index ${ }^{12}$ now shows a total of 99 OT references in the $D I, 44$ of which ${ }^{13}$ have not come from Cyprian. In regard to $\mathrm{Bk} 4$, one may detect 85 OT passages, 32 of which are independent of Cyprian.

This changes the picture somewhat and shows, among other things which shall be discussed subsequently, that when Lactantius is alluding to the OT rather than offering a direct quotation, his source of knowledge is wholly independent of the Ad Quirinum. In addition to the 99 OT allusions and citations, ${ }^{14}$ the revised index shows no less than 81 references to the Gospels and NT Epistles; all except two of these ${ }^{15}$ being paraphrastic allusions rather than quotations. This NT material falls into one of two categories; the references are either aimed at his Christian audience without being meant to be recognised by the pagan 
literati, or else they appear in the section on the life of Jesus in Bk. 4, and paraphrastically supply the narrative of the events of the ministry. Of these 79 passages, the vast majority have no parallel in either Cyprian or the known patristic sources of the DI. ${ }^{16}$ All Lactantius' references to Hebrews, for example, ${ }^{17}$ are clearly independent of the $A d$ Quirinum which does not reproduce a single text from that source. So whereas Lactantius appears to have used Cyprian as the single most complete source for his collection of OT proof texts, he still manifests a notable independence from Cyprian in many aspects of his OT scholarship, and even more so in his awareness of the NT. Even in those passages from the OT which parallel Cyprian, Lactantius' version of the text frequently departs from that of the Ad Quirinum, as the following examples of a few of the verb forms will illustrate:

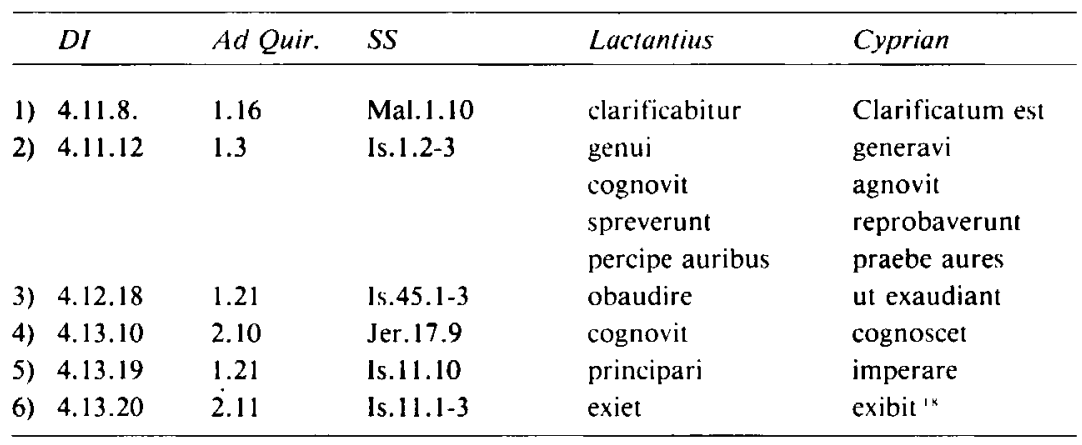

Nor can these textual changes be simply ascribed to Lactantius' desire to improve on the quality of the Latin version he is reading, for example Nos. 5-6 above show that the Lactantian forms are less classical than those of his rhetorical colleague Cyprian. Here we have a strong suggestion that an entirely different textual tradition was influencing Lactantius' thought. Where the LXX itself represents two distinct texttraditions for the same Old Testament passage, Lactantius presents an entirely different version to that followed by Cyprian. ${ }^{19}$ All of which demonstrates that Brandt's thesis, that Lactantius gains all his scriptural expertise second-hand from Cyprian, is not tenable, and his independent knowledge of scripture far more extensive than previously thought. It also clearly demonstrates, in R. M. Ogilvie's words, "that Lactantius cannot have drawn his material from the $A d$ Quirinum in its present state.", 20 
The origin of these Old Testament passages in the $D I$ which have no parallel in Cyprian have long been the source of speculation, beginning with $\mathrm{R}$. Pichon ${ }^{21}$ and continuing up to the most recent study by $\mathrm{A}$. Wlosok ${ }^{22}$ which has been widely accepted in other recent Lactantian studies $^{23}$ as showing that Lactantius used some form of Gnosticinfluenced scripture manual to provide his extra references; though this latter argument has tended to be over-inflated by the author to infer that Lactantius' theology (especially his view of revelation as sapientia religiosa) owes more to the pagan religious currents of his time than to orthodox Christianity. ${ }^{24}$

Commentators have claimed to recognise signs of this supposedly Gnostic sourcebook in his use of the Praedicatio Petri et Pauli, his use of the Theodotion tradition of the LXX, for example, or his employment of the Odes of Solomon. ${ }^{25}$ Lactantius' citation of the Praedicatio, however, can in no way be identified with the apocryphal Kerygma Petrou. ${ }^{26}$ Even if it could, the quotation in Lactantius has not the slightest 'gnostic' element about it. On top of this, the Kerygma Petrou itself is only transformed into a Gnostic-type source by the flimiest of evidence. Wlosok does so by seeing Lactantius' non-Cyprianic source as a Gnostic, anti-Judaic type of treatise (hence the Kerygma Petrou can be included in so far as it was an anti-Jewish polemic) and R. M. Ogilvie, following Wlosok, seems to wish to drag Gnosticism in at all costs, and overstates the argument: "Origen and Clement of Alexandria were among the Fathers who used its material most extensively, but its tendency is clear from the fact that Heracleon, a Gnostic at Rome in the mid-third century, availed himself of it (Origen, Com. In Ioann)." 27

The Gnostics used John's Gospel, but that is not sufficient argument to conclude John was Gnostic. On the basis of such evidence a supposedly 'Gnostic treatise' theory is compromised. Lactantius' use of the Theodotion LXX tradition for his citation of Daniel $7.13^{28}$ is taken as another sign of his 'Gnostic' source. All it shows is that Lactantius is aware of the LXX tradition that was circulating in the East and had been used by Origen. To link Lactantius in any way with the Gnostic movement through this citation ${ }^{29}$ (again one which has nothing at all theologically 'Gnostic' about it, per se) is specious reasoning. A. Wlosok $^{30}$ elevates the citation of the Odes of Solomon, $19,{ }^{31}$ and a possible allusion to Ode $15.1-6,{ }^{32}$ into a significant theological influence on Lactantius' doctrine of redemption, and this too appears an alarming inference to make from the available evidence. ${ }^{33}$ If the Odes are 
theologically significant for Lactantius in any real way, then they would stand out markedly as the only source he ever employs, even including canonical pericopes, that is individually important for him in this manner. So, too, the inference that the use of a supposedly 'Gnostic-Judaic' scripture source in the $D I$ gives evidence of his own theological bias is equally unfounded. First of all, in his use of source material Lactantius shows himself singularly uninterested in the surrounding context of the citation he employs. ${ }^{34}$ Secondly all the evidence for the Gnostic character of his non-Cyprianic source is highly controvertible, and thirdly, the use of a source whatever its theological bias, has no relevance whatsoever per se; what is important is how the citation is used and to what end in the user's theological argument. In his exposition of a doctrine of relevation throughout the $D I$, Lactantius is certainly not a 'Gnostic' in his theology of revelation or salvation. ${ }^{35}$

These examples indicate why the issue of his non-Cyprianic scriptual sources needs to be raised again and re-assessed. The first question that should arise in this regard is whether any of Lactantius' patristic sources could supply the exegetical passages which Lactantius does not owe to Cyprian.

But the times when Lactantius' exegesis echoes that of the previous Apologists are generally unhelpful to our present enquiry since most of the parallel instances are already provided with a suitable Cyprianic source. There are four of the non-Cyprianic Old Testament passages, however, which may be found in an alternative apologetic source: ${ }^{36}$
(1) Esdras
(DI) 4.18 .22
Justin Trypho $72,188^{37}$
(2) Jeremiah 11.19
4.18 .28
(3) Jeremiah 31.31
4.20.6.10
Justin Trypho 72
(4) Ps. 89.4
7.14.9.
Justin Trypho 11
Justin Trypho 81

These parallelisms with the Dialogue with Trypho are most interesting, and Justin's work does emerge as a possible source for these Lactantian exegeses. ${ }^{38}$

The first is an apocryphal quotation which Justin cites as canonical, with the complaint that the Jews have suppressed it. The text is only found in patristic literature in these two places, in Justin and Lactantius. Lactantius quotes it without comment, as if it were a canonical authority. In the second passage Justin simply offers the Jeremiah text, "let us send wood into his bread", without any exegesis, immediately after his presentation of the Esdras' text, as another example of Jewish 
censorial interference in scriptural tradition. He applies both texts to demonstrate "that the Jews deliberated about Christ, to put him to death'. Lactantius presents the Jeremian text, however, with a typological commentary on the cross and the eucharist implicity relating it to Jn. 6.26f.

It appears in a very long catena of texts, none of the others appearing in Justin, which demonstrates the necessity of the crucifixion of Jesus. In the third passage Lactantius reproduces the Jeremian text (found in Justin) again as one of a long catena of texts (none of the others appearing in Justin) to demonstrate the point that a new convenant has been established in Christ. There is a slight indication that he has a direct knowledge of Justin's text here in that the paragraph of Justin immediately following the Jeremian citation (where Christ himself is called the new law) is possibly echoed at $D I 4.17 .7 .^{39}$ And in the fourth passage Lactantius reproduces the same psalm text as Justin (with the Lord one day is a thousand years) to argue for the same theological conception -that there will be a millenial apocalyptic reign. The citation is the same, the theological context is very similar but the Lactantian treatment of the seven millenia of creation is extended independently of Justin's eschatology and it is clear from Book 7 of the $D I$ that Lactantius has many varied sources for his own scheme.

In short, then, the non-cyprianic texts which also appear in Justin, might well represent Lactantius' apologetic source the Dialogue with Trypho, but if so, it is a source on which Lactantius has elaborated independently. On the other hand Lactantius could have used an otherwise unknown apology which in turn had employed material from Justin Martyr. ${ }^{40}$ Whatever the case, Justin is not sufficient to explain the source of the forty other passages which would still have to be accounted for. If all these forty-four non-Cyprianic passages (both quotations and scriptural allusions ${ }^{41}$ are listed, certain groupings ${ }^{42}$ of texts appear to emerge.

The non-Cyprianic material represents about half of Lactantius' psalm texts,,$^{43}$ a third of his Isaian usage, ${ }^{44}$ and completely represents the apocryphal material he uses ${ }^{45}$ as well as all his references to Ekeziel ${ }^{46}$ and Daniel. ${ }^{47}$

The following index lists the non-Cyprianic passages ${ }^{48}$ on the basis of their order in Lactantius, and thus allows us to see how they relate to his theological argument: 


\begin{tabular}{|c|c|c|c|c|}
\hline \multicolumn{2}{|c|}{ Catenae } & \multirow{2}{*}{$\begin{array}{l}\text { Lactantius } \\
2.10 .3\end{array}$} & \multirow{2}{*}{$\frac{\text { Scripture }}{\text { Gen. } 1.27}$} & \multirow{2}{*}{$\frac{\text { Allusion/Citation }}{\text { A }}$} \\
\hline & 1 & & & \\
\hline & 2 & 3.19 .3 & Dan. 12.2 & A \\
\hline & 3 & 4.4 .2 & Mal. 1.6 & $\mathbf{A}$ \\
\hline & 4 & 4.8.6-9 & Ps. 104.4 & A \\
\hline & 5 & 4.10 .10 & Num. 11.31 & $\mathbf{A}$ \\
\hline & 6 & 4.10 .10 & Ps. 78.24.f & $\mathbf{A}$ \\
\hline & 7 & 4.11 .5 & Neh. 9.26 & C \\
\hline & 8 & $4.11 .11 \mathrm{f}$ & Ezek. $40 \mathrm{f}$ & A \\
\hline & 9 & 4.12 .3 & Ode Sol. 19 & C \\
\hline & 10 & 4.12 .7 & Ps. 85.12 & C \\
\hline \multirow[t]{7}{*}{ A } & 11 & 4.12 .8 & Is. 63.10 & $\mathrm{C}$ \\
\hline & 12 & 4.12 .9 & Is. 45.8 & C \\
\hline & 13 & $4.12 .12-16.19$ & Dan. 7.13 & C \\
\hline & 14 & 4.12 .18 & Is. $45.1-3$ & C \\
\hline & 15 & 4.13 .10 & Is. 19.20 & C \\
\hline & 16 & 4.13 .27 & Ps. 127.1 & C \\
\hline & 17 & 4.16 .6 & Ps. 1.1 & C \\
\hline \multirow[t]{6}{*}{ B } & 18 & $4.16 .7-10$ & Wisd. $2.12-27$ & C \\
\hline & 19 & 4.16 .14 & Ps. $72.6-7$ & C \\
\hline & 20 & 4.17 .12 & Num. 13.9 & A \\
\hline & 21 & 4.18 .14 & Ps. 35.15 & C \\
\hline & 22 & 4.18 .18 & Ps. 69.22 & C \\
\hline & 23 & 4.18.22 & ‘Esdras' & C \\
\hline \multirow[t]{5}{*}{$\mathrm{C}$} & 24 & 4.18 .26 & Ps. 94.21 & C \\
\hline & 25 & 4.18 .28 & Jer. 11.19 & C \\
\hline & 26 & 4.18 .32 & 1 K. $9.6-9$ & C \\
\hline & 27 & 4.18 .32 & 1 Chron. $7.19-22$ & $\mathrm{C}$ \\
\hline & 28 & 4.19 .9 & Hos. 13.13 & $\mathrm{C}$ \\
\hline \multirow[t]{2}{*}{$\mathrm{D}$} & 29 & $4.20 .6,10$ & Jer. 31.31 & $\mathrm{C}$ \\
\hline & 30 & $4.20 .7-9$ & Jer. 12.7 & C \\
\hline \multirow{2}{*}{$\mathrm{E}$} & 31 & 4.21 .1 & Dan. 7.13 & C \\
\hline & 32 & $4.21 .2-4$ & "Praedicatio" & $\mathrm{C}$ \\
\hline \multirow{12}{*}{$F$} & 33 & 4.29 .10 & Is. 44.6 & $\mathrm{C}$ \\
\hline & 34 & 4.29 .11 & Hos. 13.13 & $\mathrm{C}$ \\
\hline & 35 & 5.18 .13 & Gen. 2.6-7 & A \\
\hline & 36 & 5.9 .2 & Ps. 15.2 & $\mathbf{A}$ \\
\hline & 37 & 5.11 .1 & Ezek. 34.25 .28 & $\mathbf{A}$ \\
\hline & 38 & 5.23 .3 & Ezek. 34.25 & A \\
\hline & 39 & 7.14 .9 & Ps. 90.4 & $\mathrm{C}$ \\
\hline & 40 & $7.16 .1-5$ & Dan. 7.2 & $\mathbf{A}$ \\
\hline & 41 & 7.24 .3 & Is. 6.12 & $\mathbf{A}$ \\
\hline & 42 & 7.24 .7 & Is. 30.26 & $\mathbf{A}$ \\
\hline & 43 & 7.26 .2 & Ezek. 38.20-22 & $\mathbf{A}$ \\
\hline & 44 & 7.26 .4 & Ezek. 39.9-11 & A \\
\hline
\end{tabular}


The table shows that the material is only significant in Books 4, 5 and 7. The three opening books of the $D I$ have been concerned with his negative apology against the mythologists and rationalists which explains why Lactantius has not wished to employ scriptural testimony in any significant way at all. The two references listed before Book 4 consist only of the most general allusions to the scriptures. ${ }^{49}$ When Lactantius arrives at Book 4, however, he changes his apologetic method ${ }^{\text {so }}$ and begins a positive Christian catechesis in which the scriptural testimony is to play a considerable role in structuring the christology. ${ }^{51}$

This comparative explosion of scriptural usage in $\mathrm{Bk} 4$ also explains why the non-Cyprianic material is grouped here. The non-Cyprianic table tends to suggest that Lactantius is indeed dealing with some other kind of scriptural handbook which supplements the scope and interest of Cyprian. The proportion of cited texts, as distinct from general allusions, is much higher in this list than it is in the general scriptural index. In addition, when the allusions are isolated from the non-Cyprianic list (allusions that can be taken as indicative of a general or personal knowledge of scripture in Lactantius' case) they clearly fall into distinct categories:

a) Nos. 1, 2, 3, 4, 5, 6, 20, all of which are the vaguest kind of scriptural allusion and represent universal biblicisms or common facts of the history of the Jewish people: (eg. 2.10.3/Gen. 1.27, that God made man in his image or $4.10 .10 / \mathrm{Ps} .78 .24$, part of his narrative of Hebraic history to supply the detail of the quail falling in the camp) and

b) Nos. $8,36,37,38,40,41,42,43$ and 44 which are noticeably grouped together in Books 5 and 7 and equally represent commonplaces, ${ }^{52}$ this time in the context of the persecution of the just or details of the apocalyptic scene. None of the allusive materials, then, demands any kind of reference to a written source to explain its appearance in the $D I$. This is not so, however, with the remaining twenty seven passages, all of which are direct scriptural quotations. The problem of the non-Cyprianic scriptural source relates immediately to these twenty-seven instances which in turn resolve to twenty-five texts. ${ }^{53}$

Of the twenty-five, four have a relationship with Justin's Dialogue with Trypho, ${ }^{54}$ but the remaining twenty-one have no parallels 
elsewhere in Lactantius' known patristic reading, other than those that can be explained by random overlapping."

The non-Cyprianic list shows quite clearly that there are text groupings among the twenty five non-Cyprianic texts, which argues most strongly that here in the $D I$ Lactantius has taken over scriptural catenae to support his argument.

Six of these groups of catenae are quite visible in the table, three major and three minor:

a) Nos. (9-14) representing a catena of six Old Testament proof texts between $D I 412.3$ and 4.12 .18 .

b) Nos. 17-19 representing a catena of three texts between DI 4.16.6 and 4.16.14.

c) Nos. 21-27 representing a catena of seven proofs between DI 4.18.14 and 4.18.32.

d) Nos. 29 and 30 representing a catena of two proofs between $D I$ 4.20.6 and 4.20.10.

e) Nos. 31 and 32 representing a catena of two texts at DI 4.20.6-10.

f) and lastly nos. 33-34 representing another catena of two texts between $D I 4.29 .10$ and 4.29.11.

Thus a clear majority of the non-Cyprianic citations ${ }^{56}$ appear within this form of scriptural catenae. Lactantius therefore seems to be reproducing sequences of scriptural material to disrupt and revise the catena-sequences arranged by Cyprian in the $A d$ Quirinum. From reference to the OT scripture index, ${ }^{57}$ where the biblical passages are grouped according to their appearance in the text of the $D I$, it is possible to see how Lactantius reconstructs scriptural catenae of proof texts by intermingling the Cyprianic and non-Cyprianic testimonia. ${ }^{58}$

Our table in the Appendix shows that Lactantius is using the Cyprianic testimonia as his more extensive source and therefore, in all likelihood, as his basic source of scriptural proofs into which he has inserted extra material in order to present expanded scriptural demonstrations; but it also demonstrates that Lactantius has not slavishly followed the theological structure which determined Cyprian's scriptural groupings. Column I, for example, gives relatively few cases of Lactantius' textual progression following that of Cyprian, ${ }^{59}$ and in the majority of these cases the scriptural catenae rarely exceed two adjacent texts.

This suggests that both in regard to Cyprian's Ad Quirinum and the source which provided the non-Cyprianic testimonia, Lactantius applies 
a considerable amount of editorial re-arrangement to make the final scheme of the catenae of proofs very much his own. If one also brings into count the extent to which Lactantius introduces frequent allusions to the Gospels and New Testament Epistles to Book 4, then the scope and extent of his personal redaction of sources is greatly increased..$^{60}$

The three major catenae of scriptural texts (A, B and C) ${ }^{61}$ which Lactantius has gained from his non-Cyprianic source are grouped respectively in chapters 12,16 and 18 of the fourth book of the $D I$.

Chapter 12 is concerned with the virginal birth of Christ $^{62}$ and his ascension and exaltation, ${ }^{63}$ all interpreted as Christ's mission to reveal "the sacred mystery of the only true God". ${ }^{64} \mathrm{He}$ has a potential source of proof texts on these subjects in Cyprian, but prefers to use an extraneous source here. And so, of the nine proof texts he offers, only three are taken from the $A d$ Quirinum ${ }^{65}$ and these appear to be randomly selected units rather than Cyprianic catenae. There is a strong theme of anti-Jewish argument in the chapter, ${ }^{66}$ Chapter 16 interprets the suffering and rejection of Christ as a logical result of his ministry of teaching. ${ }^{67}$ Of the four Old Testament proofs he adduces, the first three are a catena drawn from the non-Cyprianic source ${ }^{68}$ and which are concluded by a reference to the suffering-servant song in Isaiah. ${ }^{69}$

This has a possible parallel in Cyprian. The final three-quarters of the chapter (vv 5-17) are given over to a bitter condemnation of the Jewish sin of the rejection of Christ, ${ }^{70}$ and $D I$ chapter 18 is concerned once more with the passion and rejection of Christ in a discernibly anti-Jewish context. So it is that the chapter is introduced with the Jews "conspiring to condemn their God through ignorance of the scriptures". ${ }^{71}$ It is the Jews who seize the Son of God and bring him to Pilate, ${ }^{72}$ and the Roman governor's role is greatly diminished. Lactantius notes only that he recorded Christ was underserving of condemnation, ${ }^{73}$ and because of hostile pressure from Herod and the Jews ${ }^{74}$ that he gave Christ into their hands. The trial of Christ, the mockery, the clothing in the scarlet robe, the crown of thorns, the salutation as King, and the giving of gall and vinegar - all are attributed to the Jews, not the Romans. ${ }^{75}$ And Lactantius then adduces scriptural and Sibylline proofs to show that it was foretold that the Jews would reject God in this way. ${ }^{76} \mathrm{He}$ finishes the chapter with two proof-texts showing that the Jewish nation would pay for this crime by the destruction of their holy city. ${ }^{77}$ 
This theme of anti-Jewish polemic runs consistently throughout most of the non-Cyprianic proof texts Lactantius uses and suggests that he is reflecting here his dependence on some other collection of canonical and non-canonical Testimonia, probably some kind of 'Adversus Judaeos' that was circulating in the Eastern Church. ${ }^{78}$ The use of this Eastern source in the composition of Book 4 is used as evidence by $R$. M. Ogilvie $^{79}$ to support the thesis that Lactantius wrote this part of the $D I$ in Nicomedia, and to counter the argument of $\mathrm{V}$. Loi ${ }^{80}$ that it was assembled when Lactantius had reached the safety of Gaul. The use of this source cannot, however, be used as reliable evidence in this debate since it is not feasible to presume any professional rhetor would ever move house, whether from Cirta to Nicomedia, or more to the point, from Nicomedia to Trier, without taking his books along with him in the ubiquitous ox-cart.

One can legitimately conclude that Lactantius used such a handbook of testimonies devoted to anti-Jewish propaganda, even that he had assimilated far more material of this nature than he was prepared to insert into the text of his $D I$ (after all here Lactantius was adressing the Roman mind, not the Jewish), because he even announces his intention to compose his own treatise Adversus Judaeos at a later date. ${ }^{81}$ But the evidence that is adduced by Wlosok (and R. M. Ogilvie following her) to describe this source as 'Gnostic-anti-Jewish' seems to go beyond its scope and is ultimately reducible to A. Wlosok's initial pre-supposition that Lactantius' conception of God, and revelation, came to him from a supposedly Hermetic religious background "before his conversion". I myself find no evidence to support the thesis of a 'conversion', and regard the notion as one of the many myths that still afflict Lactantian studies, and would argue along with $\mathrm{J}$. Stevenson ${ }^{82}$ that his Christian activity must have begun in Africa long before his journey to Asia Minor. In addition if one impartially analyses his doctrine of Revelation, it is clear that it is perfectly orthodox and none of the defining themes of Gnosticism-proper can be traced in it. ${ }^{83}$ With regard to Lactantius' use of Hermetic literature, one may similarly observe that although he uses it quite pervasively, it is by no means as extensive as his scriptural material, is introduced on apologetic motives not theological, and is quite definitely subordinated as a testimony to the scriptures themselves. ${ }^{84}$ The evidence of 'Gnosticism' in the non-Cyprianic source is far from convincing, ${ }^{85}$ but even if it were allowed, the conclusion that Wlosok suggests (that this is thereby a sign of Gnostic elements in Lac- 
tantius' thought) is an invalid inference given the available evidence from the sources, and certainly invalid in the light of what Lactantius himself has to say about Revelation.

The manner in which Lactantius has interrupted the scriptural catenae of both Cyprian, and his anti-Jewish source, ${ }^{86}$ introducing elements from one and the other, suggests that (as is the case with all his patristic sources) the theological direction and argument are rarely taken over from the texts he employs, but that he regards them as mines from which he can quarry material that will re-inforce his own argument, on his own terms.

\section{NoTES}

Corpus Scriptorum Ecclesiasticorum Latinorum.

2 Corpus Christianorum III, pars 1, 1972, 1-179.

"Divine Institutes. English tr. W. Fletcher, in Ante Nicene Christian Library, Vol. 21 (Edinburgh 1871) or M. F. McDonald, in The Fathers of the Church, Vol. 49 (Washington 1964).

4 For a fuller discussion of this problem and that of the Greek and possibly Latin collections of testimonia that seem to have pre-dated Cyprian's own work see R. Weber, CC III, pars 1. introd. LIV-LX.

5 Eg. Ad Quir. 2.3 (Quod christus idem sit sermo del) from Cyprian's catena of 6 testimonies, Lactantius selects the three most succint (DI 4.8.14-16) to demonstrate the same point as Cyprian's title. or Ad Quir. 2.6. (Quod deus Christus) where Lactantius uses three of the 18 testimonies in the same argument (DI 4.13.7-9).

- R. M. Oglivie, The Library of Lactantius (Oxford 1978) 97.

' Ibid., 98.

\& Zur Bedeutung der nichtcyprianischen Bibelzitate bei Laktanz (cited hereafter as 'Nichtcyprianische Bibelzitate', Sp. 4 . TU. 79 (1961) 234-250. cf. Ogilvie, op cit., 97-107.

9 Cf. tabulated list, Ogilvie, op. cit., 99-100.

10 Jn. 1.1-3, DI 4.8.16, Lk 3.22, DI 4.15.3, and Jn 2.19, DI 4.18.4 (Ogilvie's list nos. 7, 39 , and 50 ) the last two of this set are non-Cyprianic.

"Lactantius' NT material, with but one exception, is allusive not cited, therefore to enumerate only $3 \mathrm{NT}$ references in $D I, \mathrm{Bk}, 4$ grossly distorts the picture. In fact at least 33 can be traced only 4 of which have any parallel in the Ad. Quirinum.

12 Cf. Appendices 1-3 of P. McGuckin, Researches into the Divine Institutes of Lactantius. Diss. Durham 1980.

13 Though there are 2 reduplicated citations: Dan. 7.13 which appears at $D I 4.12 .12 \mathrm{f}$ and 4.21.1, and Hos. 13.13. which appears at $D I 4.19 .9$ and 4.29.11, together with one set of parallel references Num. 11.31 and Ps. 72.24 at $D I 4.10 .10$. This leaves a truer number of 41 instances not found in Cyprian.

14 This figure includes reference to three apocryphal books: Esdras, Praedictio Petri et Pauli, and the Odes of Solomon. 
is Jn. 1.3. at $D I 4.8 .16$, and Jn. 2.19 at $D I 4.18 .4$. The former has a possible source in Ad Quir. 2.3, the latter no parallel in Cyprian.

16 Out of 75 separate and distinct NT passages in the $D I$, only 21 can have a possible Cyprianic parallel, but in regard to each of these NT sources Lactantius presents other material from all the different scriptural books which is completely independent of Cyprian. This argues that the Ad Quir. is not a significant source for any of his NT. knowledge: eg. of the 15 references to Mtt's Gospel in the $D I$, only 2 are cited by Cyprian's Ad Quir.; of the 16 allusions to 1 Cor. 5 are without Cyprianic parallel and the remaining 11 are as randomly scattered in Cyprian as they are in Lactantius. If the $D I$ had depended on its knowledge of Paul via Cyprian, text-groupings would have emerged.

"14 instances.

is Cp. R. M. Ogilvie, The Library of Lactantius, 101f.

19 DI 4.12.12-16. Ad Quir. 2.26 (Dan. 7.13-14). Cyprian follows the main LXX tradition: et data est ei potestas regia, Lactantius follows the Theodotion tradition: et datum est ei regnum et honor et imperium.

20 R. M. Ogilvie, The Library of Lactantius, 100. The author suggests that Lactantius used a basic scriptural framework from a "revised or careless edition of Cyprian's Testimonia" (ibid., 106-107) and remodelled it with scriptural material of his own selection.

$21 \quad$ Lactance (Paris 1901) 202-207.

22 Nichtcyprianische Bibelzitate, Sp. 4. TU. 79 (1961) 234-50.

23 Eg. A. Grillmeier, Christ in Christian tradition, Vol 1, 190-206; V. Loi Lattanzio; E. Heck, Die dualistischen Zusätze und die Kaiseranreden bei Laktanz. AHAW Heidelberg, 1972.

24 Wlosok's theory of Lactantian 'Gnosticism', based mainly on his use of Hermetic and Platonic texts, has been successfully rebutted by A. Nock, The Exegesis of Timaeus $28 \mathrm{C}$, Vig. Chr. 16 (1962) 79-86. See also J. Stevenson, Lactantius and the Hermetica, Classical Review 13 (1963) 81, but Harnack had written long before: "Teachers like Commodian, Arnobius and Lactantius, however, wrote as if there had been no Gnostic movement at all, and as if no Antignostic Church theology existed". cp. History of Dogma (London 1896). Theol. transl. Lib. vol 2, 244. Indeed it can be most strongly argued, against Wlosok's conception, that religiosa sapientia in Lactantius is not an intellectual notion, but a liturgical and ethical one.

2" DI 4.21.2-4, 4.12.12-16, and 4.12 .3 respectively.

${ }^{26}$ On which identification the 'Gnostic' theory relies, but cf. E. Hennecke $N T$ Apocrypha vol. 2 (London 1975) 94-102 but especially p. 93.

2) Ogilvie, The Library of Lactantius 107 . Hennecke also denies that the work Heracleon cites can be identified with the Kerygma; Hennecke op. cit., 100-101, so the whole argument of Wlosok and Ogilvie is shaken.

28 DI 4.12.12.f.

29 As R. M. Ogilvie, who states: "the fact that he (Theodotion) was a Gnostic who lapsed into Judaism may be more relevant for appreciating the general tendency of the anthology of scriptural quotations which Lactantius used." op. cit., 102 fn. 5.

30 Nichtcyprianische Bibelzitate, 242-247, esp. 244 fn. 2 - an analysis Grillmeier adopts enthusiastically, Christ in Christian tradition Vol. 1, 192-193.

31 DI 4.12.3.

32 DI 6.9.13. 
33 Lactantius cites Ode 19 (DI 4.12.3) to give a proof text in addition to that of Is. 7.14, on the virgin birth. It should be noted that he does not have a wide choice of proof-texts on this theme. The ode is also presented without elaboration, simply as one proof among others. Nothing suggests a particularly significant source. The supposed allusion to Ode 15 at $D I 6.9 .13$, would seem to have a more probable origin in the lost work of Asclepiades, De Providentia. See P. McGuckin, Researches, 132-140.

${ }^{34}$ Except for Cicero's theological works whose argumentation he evidently knows intimately, and can allude to more explicitly with some confidence that his literati audience will recognise the allusions.

35 Cf. P. McGuckin, Researches, 217-348.

36 It is interesting to note that even where Lactantius parallels the theological argument of Tertullian most intimately ( $a d v$. Prax 18, DI 4.29), he presents an utterly different catena of scriptural proofs: Tertullian gives Is. 45.5, 45.5, and 45.18, Lactantius cites Is. 45.14, 44.6, Hos. 13.14.

37 An apocryphal text found only in Justin and Lactantius.

38 L. Alfonsi argues a direct dependence on Justin (cf. Instituto di Lombardi. Scienze e Lettere 82 (1949) 19-27).

${ }^{39} \mathrm{DI}$ 4.17.7 denuntiavit ... quod filium suum id est vivam praesentemque legem missurus esset ... ut denuo per eum qui esset aeternus, legem sanciret aeternam. Cp. Justin, Trypho 11 (PG 6.497B). V. Loi suggests this titular usage in Lactantius has a basis in Kerygma Petrou (Lattanzio, 259 fn. 119, cp. p. 17 fn. 66) for Clement of Alexandria witnesses its use in the Kerygma. But the concept is not a rare one, nor is there any evidence to suggest Lactantius even knows the Kerygma, and a closer source can be found in Cyprian's $A d$ Quirinum 1.10 (quod lex nova dari haberet) where the titles Lex and Verbum domini are associated in Is. 11.3, and Cyprian applies Mtt 17.5 to suggest its fulfilment in Christ.

40 Or some form of manual which Justin himself has used independently.

4. The allusions are differentiated from the citations, as in the subsequent table by the respective letter $\mathrm{A}$, or $\mathrm{C}$, in the final column.

42 These catenae are illustrated in the subsequent table by being bracketed together in column 1.

$43 \quad 12$ out of 25 instances.

447 out of 21 instances.

4s 3 instances.

46 instances.

45 instances. The version of Dan. 7.13 used by Cyprian in Ad Quir. 2.26 is not the Theodotion text used by Lactantius at $4.12 .12 \mathrm{f}$.

48 Although the list enumerates 44 instances nos 4 and 5 are a parallel (one or the other text is alluded to). In addition nos. (13 and 31 ) and (28 and 34) consist of reduplications, so the true figure of separate texts is 41 .

${ }^{49}$ DI 2.10.3 - that God created Man in his image. DI 3.19.3 - that the scriptures teach that souls will be judged.

so Cf. DI 3.30.9-10.

st Cp. DI 4.5.3. This passage introduces a chapter wholly devoted to introducing the role of scriptural testimony in Bk. 4.

52 Eg. nos. 37-38 where Lactantius applies Ezekiel's epithet of 'the beasts' to describe the persecutors, or no. 40 where he uses elements from Daniel to describe the apocalyptic unrest among the kingdoms of the earth. 
33 Allowing for the reduplications, nos. $13+31,28+34$.

34 Nos. 23, 24, 29 and 39. Lactantius has either first-hand or second-hand knowledge of these biblicisms of the Dialogue. The first three references relate to an anti-Jewish polemic, the last is the millenial application of Ps. 90.4.

ss Nos. 6 and 17 are also used in Cyprian's De Bono Patientiae and the De Unitate, but neither treatise provides any other sign of literary parallelism with the $D I .12$ of the texts (Nos: 1, 4, 5, 6, 14, 17, 22, 25, 29, 31, 33, and 35) appear randomly throughout a number of Tertullian's treatises (Adv. Marc., Ieiun., De Carne, Adv. Iud., Pudicitia, Spectaculis, De Res., Adv. Hermog., De Bapt., Adv. Prax.) and the Adv. Marc. and the Adv. Iudaeos together account for ten of the twelve texts. The only work of Tertullian, however, which provides other supporting signs of literary parallelism with the $D I$ is the Adv. Prax. and the latter treatise only represents text no. 33 on our list. All in all no pattern of exegetical dependence emerges from these instances, which makes it highly unlikely that Lactantius has used the Latin Fathers as a source for this scripture material.

56 A total of 23 instances.

57 At the end of this present study.

s8 Cp. Appendix Nos. 23-31 where material from each source is evenly distributed; or nos. 59-73 where material from catena $\mathrm{C}$ of the non-Cyprianic index (cited previously) has been used to supplement the original catena of Cyprian.

so See appendix column 1. The order of Cyprianic text in Lactantius is generally random, excepting those short catenae he has directly copies viz; 8-9, 18-19, 21-22, 23-24, 32-34, 35-36, 43-44, 54-56, 68-71, 74-75, 76-77.

so Cp. the abundant amount of NT allusions introduced in Bk 4. (P. McGuckin, Researches, 530-532). Of these 33 allusions only 4 have a corresponding parallel in the $A d$ Quirinum. Each of these 4 instances is set within a chain of other allusions to the same NT source which Lactantius has collated independently. One may thus draw the inference that this NT parallelism with the Ad Quir. is purely coincidental and that all Lactantius' NT knowledge is personal.

61 See the preceding table.

62 DI 4.12.1-10.

${ }^{63}$ DI 4.12.12-22.

64 DI 4.12.11.

os DI 4.12.4 Ad Quir. 2.9, DI 4.12.10 Ad Quir. 2.21 and DI 4.12.17 Ad Quir.

2.26).

66 See eg. DI 4.12.11.13.

${ }^{67}$ Cp. DI 4.16.4.14B.

68 See Appendix, the citation of Wisdom. 2.12f. at DI 4.16.7-10 is not drawn from $A d$ Quir. 2.14. since it includes elements Cyprian has excised.

69 Is. 53.1-6. DI 4.16.15. Ad Quir. 2.13.

70 For the terms of this anti-Jewish argument cp. DI 4.16.5.6.11 and 17.

"DI 4.18.1.

12 DI 4.18.3-4.

${ }^{3}$ DI 4.18.5.

14 DI 4.18.6.

"s DI 4.18.6b-7 (Lactantius is probably indebted for this perspective to Luke $22.63 \mathrm{f}$.).

16 Particularly the Sibylline proof at $\mathbf{4 . 1 8 . 2 0}$ which he says "rebukes the land of Judaea". He appears to attribute the crowning with thorns to the Jews, and the Isaian text at 4.18.24 lays the whole blame for the passion at their door. 
"Both from a non-Cyprianic source: 1K.9.6-9, 1 Chron. 7.19-22, but $D I 4.18 .33$ passes outside the canonical versions altogether.

78 It must have been in the Eastern Church:

a) because the text of Dan. 7.13 at DI 4.12.12 follows the Theodotion tradition not the main LXX version usually followed in the West (cp. Ad Quir. 2.26)

b) because the African Canon classed the Odes of Solomon as apocryphal whereas at $D I$ 412.3 Lactantius evidently regards them as scriptural 'words of Solomon' (cp. A. Wlosok, Nichtcyprianische Bibelzitate, 242-244.)

c) because Eusebius of Caesarea twice, independently, repeats Lactantius' exegesis (cp. Zech. 3.1-8, DI 4.14.6-9) and Eusebius, Ecl. Proph. 123.23f) eg. Lactantius (in quos nihil congruit) denies the applications of the prophecy to the two earlier Joshuas, Eusebius denies its application to the priestly Joshua (mēdamoss ekeina to legomeno harmonei...) and again (cp. DI 4.20.13 and Eusebius, Ecl. Proph. 202.2f). See Wlosok op. cit., 241. n. 2. and R. M. Ogilvie. The Library of Lactantius, 106. This suggests that Eusebius is privy to the same compilation of texts as Lactantius used earlier. Eusebius also refers to Odes of Solomon 19, and once more an anti-Jewish context is in evidence (Dem. Evang. 10.499 c-d, DI 4.12.3). Lactantius and Eusebius cite different parts of this Ode.

79 Library of Lactantius, 106.

80 V. Loi, Il libro quattro delle DI fu da Lattanzio composto in Gallia? Mélanges Mohrmann, Nouveau recueil, 1973, 61-79). Loi argues from the eschatological elements in the paschal liturgy at $D I 7.19 .3 \mathrm{f}$, and from the date of the crucifixion at 4.10.18 (March 23rd, 15th year of Tiberius, the consulship of C. Rubellius Geminus and C. Fusius Geminius, A.U.C. 782) that Lactantius is reflecting practices of the Gallic Church.

${ }^{81} \mathrm{Cp}$. DI 7.1.26. The materials must have already been at hand, therefore, to prompt such a work.

${ }^{82}$ Life and literary activity of Lactantius, 666, 674.

83 Lactantius' central christological argument (that God-in-flesh is the perfect teacher of truth to all men) is a direct contradiction of all that is normally meant by 'Gnostic theory'.

s4 Cf. P. McGuckin, Researches, 147-171. See J. Stevenson, Lactantius and the Hermetica, Classical Review 13 (1963) 80-81.

s Eg. (a) that the non-Cyprianic source has Gnostic tendencies since it embraces the Odes of Solomon; (b) that it has given Lactantius an extra-canonical logion at 4.8.1 (beatus qui erat, antequam nasceretur) found elsewhere only in Gospel of Thomas, Logion 19, and Irenaeus Epid. 43 - in fact Lactantius cites this as a Jeremian text and it can be read as his own paraphrastic version of Jer. 1.5B. following on from $5 \mathrm{~A}$ which is cited immediately before; (c) that Lactantius prefers the text tradition at 4.16 .10 which replaces malitia with stultita: cp. A. Wlosok, Nichtcyprianische Bibelzitate, 238, 242-7. R. M. Ogilvie, Library of Lactantius, 106.

Bo See the subsequent table in the Appendix.

Southampton, LSU College, The Avenue, England. 


\section{APPENDIX}

A Table of the O.T. citations in the Divine Institutes

\begin{tabular}{|c|c|c|c|c|}
\hline & $\begin{array}{l}\text { Cyprian } \\
\text { Ad Quirinum }\end{array}$ & Lactantius & Scripture & $\begin{array}{l}\text { Citation } \\
\text { of Allusion }\end{array}$ \\
\hline 1 & & 2.10 .3 & Gen. 1.27 & A \\
\hline 2 & & 3.19 .3 & Dan. 12.2 & $\mathbf{A}$ \\
\hline 3 & 1.21 & 4.2 .5 & Is. 55.4 & $\mathbf{A}$ \\
\hline 4 & & 4.4 .2 & Mal. 1.6 & $\mathbf{A}$ \\
\hline 5 & 2.1 & $4.6 .6-8$ & Prov. 8.22-31 & $\mathrm{C}$ \\
\hline 6 & 1.21 & 4.8 .1 & Jer. 1.5 & $\mathbf{A}$ \\
\hline 7 & & 4.8.6-9 & Ps. 104.4 & $\mathbf{A}$ \\
\hline 8 & 2.3 & 4.8 .14 & Ps. 33.6 & $\mathrm{C}$ \\
\hline 9 & 2.3 & 4.8 .14 & Ps. 45.1 & C \\
\hline 10 & 2.1 & 4.8 .15 & Eccles. 24.5 & $\mathrm{C}$ \\
\hline 11 & 2.5 & 4.10 .7 & Ex. 23.20 & $\mathbf{A}$ \\
\hline 12 & & 4.10 .10 & Num. 11.31 & $\mathbf{A}$ \\
\hline 13 & & 4.10 .10 & Ps. 78.24 & \\
\hline 14 & 1.2 & 4.11 .4 & Jer. 25.4-6 & C \\
\hline 15 & & 4.11 .5 & Neh. 9.26 & C \\
\hline 16 & 1.2 & 4.11 .6 & $1 \mathrm{~K} 19.10$ & $\mathrm{C}$ \\
\hline 17 & 1.16 & 4.11 .8 & Mal. 1.10 & C \\
\hline 18 & 1.21 & 4.11 .9 & Ps. $18.43-4$ & $\mathrm{C}$ \\
\hline 19 & 1.21 & 4.11 .10 & Is. 66.18 & C \\
\hline 20 & & 4.11 .11 & Ez. 40 passim & $\mathbf{A}$ \\
\hline 21 & 1.3 & 4.11 .12 & Is. 1.2 & C \\
\hline 22 & 1.3 & 4.11 .13 & Jer. 8.7-9 & C \\
\hline 23 & & 4.12 .3 & Ode Sol 19 & C \\
\hline 24 & 2.9 & 4.12 .4 & Is. 7.14 & C \\
\hline 25 & & 4.12 .7 & Ps. 85.12 & C \\
\hline 26 & & 4.12 .8 & Is. 63.10 & C \\
\hline 27 & & 4.12 .9 & Is. 45.8 & C \\
\hline 28 & 2.21 & 4.12 .10 & Is. 9.5 & C \\
\hline 29 & & $4.12 .12-16,19$ & Dan. 7.13 & C \\
\hline 30 & 2.26 & 4.12 .17 & Ps. 110.1 & C \\
\hline 31 & & 4.12 .18 & Is. $45.1-3$ & C \\
\hline 32 & 2.6 & 4.13 .7 & Is. $45.14-16$ & C \\
\hline 33 & 2.6 & 4.13 .8 & Baruch 3.36 & $\mathrm{C}$ \\
\hline 34 & 2.6 & 4.13 .9 & Ps. $45.6-7$ & $\mathrm{C}$ \\
\hline 35 & $(2.10)$ & 4.13 .10 & Jer. 17.9 & $\mathrm{C}$ \\
\hline 36 & $(2.10)$ & 4.13 .10 & Num. 24.17 & C \\
\hline 37 & & 4.13 .10 & Is. 19.20 & $\mathrm{C}$ \\
\hline 38 & 1.3 & 4.13 .18 & Ps. 28.4-5 & C \\
\hline 39 & 1.21 & 4.13.19 & Is. 11.10 & C \\
\hline
\end{tabular}




\begin{tabular}{|c|c|c|c|c|}
\hline & $\begin{array}{l}\text { Cyprian } \\
\text { Ad Quirinum }\end{array}$ & Lactantius & Scripture & $\begin{array}{c}\text { Citation } \\
\text { of Allusion }\end{array}$ \\
\hline 40 & 2.10 & 4.13 .20 & Is. 11.1-3 & C \\
\hline 41 & 1.15 & 4.13 .22 & 2 Sam. $7.4 f$ & $\mathrm{C}$ \\
\hline 42 & & 4.13 .27 & Ps. 127.1 & C \\
\hline 43 & 1.17 & 4.14 .4 & Ps. 110.3-4 & C \\
\hline 44 & 1.17 & 4.14 .5 & 1 Sam. 2.35 & C \\
\hline 45 & $2.13 / 2.16$ & 4.14.6-16 & Zech. 3.1-8 & C \\
\hline 46 & 2.8 & 4.15 .3 & Ps. 2.7 & C \\
\hline 47 & 2.7 & 4.15 .7 & Is. $35.3-6$ & A \\
\hline 48 & & 4.16 .6 & Ps. 1.1 & C \\
\hline 49 & (Parts only) (2.14) & $4.16 .7-10$ & Wisd. 2.12-27 & C \\
\hline 50 & & 4.16 .14 & Ps. 72.6-7 & C \\
\hline 51 & 2.13 & 4.16 .15 & Is. $53.1-6$ & C \\
\hline 52 & 1.10 & 4.17 .3 & Micah 4.2 & $\mathrm{C}$ \\
\hline 53 & 1.18 & 4.17 .6 & Dt. 18.17 & $\mathrm{C}$ \\
\hline 54 & $(1.8)$ & 4.17 .8 & Jer. 4.3 & $\mathrm{C}$ \\
\hline 55 & 1.8 & 4.17 .9 & Dt. 30.6 & $\mathrm{C}$ \\
\hline 56 & 1.8 & 4.17 .9 & Josh. 5.2 & $\mathrm{C}$ \\
\hline 57 & & 4.17 .12 & Num. 13.9 & $\mathbf{A}$ \\
\hline 58 & 3.56 & 4.17 .17 & 1 Sam. 16.7 & A \\
\hline 59 & 2.13 & 4.18 .13 & Is. 50.5 & $\mathrm{C}$ \\
\hline 60 & & 4.18 .14 & Ps. 35.15 & $\mathrm{C}$ \\
\hline 61 & 2.13 & 4.18 .16 & 1s. 53.7 & $\mathrm{C}$ \\
\hline 62 & & 4.18 .18 & Ps. 69.22 & $\mathrm{C}$ \\
\hline 63 & & 4.18 .22 & Esdras & $\mathrm{C}$ \\
\hline 64 & 2.15 & 4.18 .24 & Is. $53.8,9,12$ & $\mathrm{C}$ \\
\hline 65 & & 4.18 .26 & Ps. 94.21 & $\mathrm{C}$ \\
\hline 66 & 2.15 & 4.18 .27 & Jer. 11.18 & $\mathrm{C}$ \\
\hline 67 & & 4.18 .27 & Jer. 11.19 & $\mathrm{C}$ \\
\hline 68 & $(2.20)$ & 4.18 .28 & Num. 23.19 & $\mathrm{C}$ \\
\hline 69 & 2.20 & 4.18 .29 & Dt. 28.66 & $\mathrm{C}$ \\
\hline 70 & 2.20 & 4.18 .29 & Zech. 12.10 & $\mathrm{C}$ \\
\hline 71 & 2.20 & 4.18 .30 & Ps. 22.17-19 & $\mathrm{C}$ \\
\hline 72 & & 4.18 .32 & 1 Chron. $7.19-22$ & $\mathrm{C}$ \\
\hline 73 & & 4.18 .32 & IK $9.6-9$ & $\mathrm{C}$ \\
\hline 74 & 2.23 & 4.19 .3 & Amos. 8.9 & $\mathrm{C}$ \\
\hline 75 & 2.23 & 4.19 .4 & Jer. 15.9 & $\mathrm{C}$ \\
\hline 76 & 2.24 & 4.19 .8 & Ps. 3.5 & $\mathrm{C}$ \\
\hline 77 & 2.24 & 4.19 .8 & Ps. 16.10 & $\mathrm{C}$ \\
\hline 78 & 2.25 & 4.19 .9 & Hos. 6.2 & $\mathrm{C}$ \\
\hline 79 & & 4.19 .9 & Hos. 13.13 & $\mathrm{C}$ \\
\hline 80 & & $4.20 .6,10$ & Jег. 31.31 & $\mathrm{C}$ \\
\hline 81 & & $4.20 .7-9$ & Jer. 12.7 & $\mathrm{C}$ \\
\hline 82 & 2.7 & 4.20 .12 & Is. 42.6 & $\mathrm{C}$ \\
\hline
\end{tabular}




\begin{tabular}{|c|c|c|c|c|}
\hline & $\begin{array}{l}\text { Cyprian } \\
\text { Ad Quirinum }\end{array}$ & Lactantius & Scripture & $\begin{array}{l}\text { Citation } \\
\text { of Allusion }\end{array}$ \\
\hline 83 & & 4.21 .1 & Dan. 7.13 & C \\
\hline 84 & & $4.21 .2-4$ & $\begin{array}{l}\text { Praedicatio } \\
\text { Petri-Pauli }\end{array}$ & C \\
\hline 85 & & 4.29 .10 & Is. 44.6 & C \\
\hline 86 & & 4.29 .11 & Hos. 13.13 & C \\
\hline 87 & 1.3 & 4.30 .1 & Jer. 2.13 & $\mathbf{A}$ \\
\hline 88 & & 5.9 .2 & Ps. 15.2 & $\mathbf{A}$ \\
\hline 89 & & 5.11 .1 & Ez. $34.25,28$ & $\mathbf{A}$ \\
\hline 90 & 2.28 & 5.13 .5 & Ps. 50.1 & $\mathbf{A}$ \\
\hline 91 & & 5.18 .13 & Gen. 2.6-7 & $\mathbf{A}$ \\
\hline 92 & & 5.23 .3 & Ez. 34-5 & $\mathbf{A}$ \\
\hline 93 & & 7.14 .9 & Ps. 90.4 & C \\
\hline 94 & & $7.16 .1-5$ & Dan.7.2 & $\mathbf{A}$ \\
\hline 95 & 3.31 & 7.20 .5 & Ps. 1.5 & $\mathbf{A}$ \\
\hline 96 & & 7.24 .3 & Is. 6.12 & $\mathbf{A}$ \\
\hline 97 & & 7.24 .7 & Is. 30.26 & $\mathbf{A}$ \\
\hline 98 & & 7.26 .2 & Ez. $38.20-22$ & $\mathbf{A}$ \\
\hline 99 & & 7.26 .4 & Ez. $39.9-11$ & A \\
\hline
\end{tabular}

